\title{
Analysis of Socio-Economic Impact of The Community Empowerment Program for Weaver Woman (Perempuan Penenun Ikat) in Letmaffo Village, Insana Tengah, Nort Central Timor District
}

\author{
Hilaria Diana Wati Nese Tuames ${ }^{1}$, Petrus Kase $^{2}$, Nursalam ${ }^{3}$ \\ Masters Program in Administration Science Nusa Cendana University ${ }^{1,2,3}$ \\ Email :Watituames694@gmail.com
}

(Received: October 24-2020; revised: November 24-2020; published: December 31-2020)

\begin{abstract}
This research is intended to analyze and describe the Socio-Economic Impact of the Ikat Weaving Women's Group Empowerment Program in Letmaffo Village, Insana Tengah District, North Central Timor Regency. To answer this problem, it is supported by various theories that have relevance to the research phenomenon. This research is a qualitative study using the Milles and Huberman data analysis technique. The results of the study explain that the socio-economic impact on the weaving empowerment group also faces many obstacles, namely related to indicators of increasing household economy, this has not been going well because the economic income of group members has even decreased due to low productivity results and low prices woven fabrics in the market, another obstacle is the indicator of the development of the group's economic structure on this indicator, the goal is that this group of weaving ties must have a market place or place to market productivity results but this has not been achieved so that the village of Letmaffo weaving group still uses the long time in sales even productivity. The factors that support and hinder the socioeconomic impact on the empowerment of the Letmaffo village weaving group are lack of capital, limited human resources, weak business networks, use of traditional production tools and limited market access.
\end{abstract}

Key words: socio-economic impact, empowerment of the weaving group.

\section{INTRODUCTION}

The existence of woven fabrics in North Central Timor Regency is able to penetrate the global market and is able to introduce its products, both nationally and internationally. This has become a bright spot for ikat craftsmen to continue to develop and create ikat fabrics in the business world. Seeing that the woven cloth is a local culture that must be preserved, so that community empowerment, especially women, is needed with the aim of improving the quality of life of the community, both socially, economically and culturally, besides that it can also improve the region's economy by developing the existing potentials.

The empowerment of a group of women craftsmen of weaving in North Central Timor Regency is used as a community small business to support the economic growth of the community in that region. The woven cloth is a cultural heritage that is capable of producing the speed of the regional economy. The handicraft of weaving that is done in TTU district is a very diverse traditional ikat craft.

The group of women artisans, Suf Ana Letmaafo, in Letmafo Village is a small part of the group that engages in small handicraft businesses that rely purely on human hands. The woven cloth craftsman in Letmafo village is one of the woven fabrics in the Insana Tengah sub-district which has a program to improve the skills and creativity of their family members in the field of 
weaving. These members have the determination to educate and train their family members to be creative, work, and independent so that it is hoped that women can increase family economic income. The women's group empowerment program in Letmafo Village is carried out regularly every day. Weaving activities by the weaving group in the village of Letmafo still have many obstacles, including still using traditional weaving tools which affect the production output every year.

This can be seen in the data from the table 1 types of fabric motifs, the amount of production and the weaving price of the Letmafo Village Ikat Weaving group.

Table 1.

Types and motifs of fabrics, production quantities and weaving prices

\begin{tabular}{|c|c|c|c|c|c|c|c|c|}
\hline \multicolumn{2}{|c|}{$\begin{array}{l}\text { Types and motifs of } \\
\text { fabrics }\end{array}$} & \multicolumn{5}{|c|}{$\begin{array}{c}\text { Number of fabrics produced / } \\
\text { group / year }\end{array}$} & \multicolumn{2}{|c|}{ Price / sheet ( Rp) } \\
\hline & & 2015 & 2016 & 2017 & 2018 & 2019 & 2015 & 2020 \\
\hline \multirow{6}{*}{$\begin{array}{l}\text { Buna } \\
\text { Bata }\end{array}$} & Tais & $70 \mathrm{lbr}$ & 66 & 55 & 60 & 50 & 350.000 & 850.000 \\
\hline & & & lbr & lbr & lbr & lbr & & \\
\hline & Beti & $60 \mathrm{lbr}$ & 50 & 50 & 45 & 45 & 450.000 & 900.000 \\
\hline & & & $\mathrm{lbr}$ & $\mathrm{lbr}$ & lbr & $\mathrm{lbr}$ & & \\
\hline & Selendang & $60 \mathrm{lbr}$ & 60 & 55 & 50 & 50 & 200.000 & 200.000 \\
\hline & & & $\mathrm{lbr}$ & $\mathrm{lbr}$ & lbr & lbr & & \\
\hline \multirow[t]{4}{*}{ Buna Asli } & Tais & $15 \mathrm{lbr}$ & $\begin{array}{c}10 \\
\mathrm{lbr}\end{array}$ & $9 \mathrm{lbr}$ & $5 \mathrm{lbr}$ & $5 \mathrm{lbr}$ & 1.250 .00 & 3500.000 \\
\hline & Beti & $15 \mathrm{lbr}$ & $\begin{array}{l}10 \\
\mathrm{lbr}\end{array}$ & $9 \mathrm{lbr}$ & $5 \mathrm{lbr}$ & $5 \mathrm{lbr}$ & 2.500 .000 & 5.500 .000 \\
\hline & Selendang & $40 \mathrm{lbr}$ & 40 & 42 & 37 & 35 & 500.000 & 500.000 \\
\hline & & & lbr & lbr & lbr & $\mathrm{lbr}$ & & \\
\hline \multirow{6}{*}{ Sotis } & Tais & $60 \mathrm{lbr}$ & 50 & 50 & 45 & 45 & 150.000 & 650.000 \\
\hline & & & lbr & lbr & lbr & lbr & & \\
\hline & Beti & $55 \mathrm{lbr}$ & 40 & 42 & 37 & 35 & 350.000 & 750.000 \\
\hline & & & lbr & lbr & lbr & lbr & & \\
\hline & Selendang & $60 \mathrm{lbr}$ & 50 & 50 & 45 & 45 & 100.000 & 100.000 \\
\hline & & & $\mathrm{lbr}$ & lbr & $\mathrm{lbr}$ & lbr & & \\
\hline \multirow[t]{6}{*}{ Futus } & Tais & $40 \mathrm{lbr}$ & 40 & 42 & 37 & 35 & 450.000 & 1.150 .000 \\
\hline & & & lbr & lbr & lbr & lbr & & \\
\hline & Beti & $50 \mathrm{lbr}$ & 47 & 42 & 37 & 35 & 750.000 & 1.500 .000 \\
\hline & & & $\mathrm{lbr}$ & lbr & lbr & lbr & & \\
\hline & Selendang & $60 \mathrm{lbr}$ & 60 & 50 & 50 & 45 & 250.000 & 250.000 \\
\hline & & & lbr & $\mathrm{lbr}$ & lbr & lbr & & \\
\hline
\end{tabular}

*lbr : sheet

Source: Letmafo village weaving group 2020. 


\section{8 | Jurnal Ilmiah Ilmu Administrasi Publik: Jurnal Pemikiran dan Penelitian Administrasi Publik \\ Volume 10 Number 2, July-December 2020. Page 446-453}

Based on the table above, it shows that there are 4 types of motifs produced by the Letmafo village weaving group with price variations according to the type of motif produced. From the data above, it is also seen that the production of woven fabrics produced by the group since 20152019 has decreased every year. So that it has an impact on the income or income of each member of the Letmafo village weaving group.

Another problem in empowering the Letmafo village weaving group is the lack of quality human resources for group members. This can be seen in table 2 regarding the education level data of the Letmafo village weaving group.

Table 2

Member Education LevelLetmafo Village Ikat Weaving Group

\begin{tabular}{lll}
\hline No & Name / Position & Last education \\
\hline 1. & Ermalinda Usfinit /Ketua & Senior High School \\
\hline 2. & Katarina Usfinit / Sekertaris & Junior high school \\
\hline 3. & Bernadetha Eno /Bendahara & Junior high school \\
\hline 4. & Imelda Usfinit/Anggota & Primary School \\
\hline 5. & Martha Funan/Anggota & Primary School \\
\hline 6. & Theresia Eta/Anggota & - \\
\hline 7. & Anastasia Sau/Anggota & - \\
\hline 8. & Veronika Sni/Anggota & - \\
\hline 9. & Asetriana Tnomel/Anggota & Primary School \\
\hline 10. & Anicia Maria Fernandes/Anggota & - \\
\hline 11. & Martha Afoan/Anggota & Primary School \\
\hline 12. & Maria Balok/Anggota & - \\
\hline 13. & Nivianti Balok/Anggota & - \\
\hline 14. & Theresia Balok/Anggota & Primary School \\
\hline 15. & Klara Sani/Anggota & Junior high school \\
\hline 16. & Sabina Haki/Anggota & Primary School \\
\hline 17 & Wilhelmina Haki/Anggota & Primary School \\
\hline
\end{tabular}

Source: Letmafo Village Iktat Weaving Group 2020

The data above shows that members of the Letmafo village weaving group show a lack of human resources because many group members have graduated from primary school and some do not finish at the education level. This has an impact on empowerment patterns and group business development. Where because the low level of education of group members causes miscommunication during the socialization of related agencies and lack of understanding regarding the use of production technology tools.

The Letmafo village tenun ikat empowerment group is included in the small and medium enterprises which still lacks and need assistance related to: capital, marketing, lack of enthusiasts and consumers, lack of production materials, and determining the selling price is still below 
average. The problems above related to the empowerment of the weaving group are influenced by the lack of attention from the local government in assistance, assistance with production tools, and marketing of products. So that synergy is needed between the weaving groups, the government, and the private sector to join hands and jointly develop the empowerment of the Letmaffo village weaving group so that it has an impact on socio-economic conditions and increases the group business income and the income of each member of the Letmafo village weaving group.

Based on this phenomenon, the authors are interested in conducting a research entitled "The Socio-Economic Impact of the Ikat Weaving Women's Group Empowerment Program in Letmaffo Village, Insana Tengah District, North Central Timor Regency"

\section{METHOD}

The method used in this research is descriptive qualitative with an exploratory approach. The focus of this research is to analyze and describe the socio-economic impact of the Letmaffo village weaving group empowerment program. The data collection techniques in this study were interviews, observation and document study, while the data analysis techniques were Miles and Huberman. Sugiono (2002).

\section{RESULT AND DISCUSSION}

\section{Empowerment of the Letmaffo Village Weaving Tenun Ikat Group}

Women's empowerment is a systematic and planned effort to achieve gender equality and equality in family and community life. Empowering women as human resources, the potential that women have in terms of quantity and quality is not below that of men. Empowerment of women aims to create women who are independent, capable of digging and exploiting their potential to be free from poverty.

According to Haryono Suyono (1998), it illustrates the empowerment of women as follows: "Empowerment and human development, especially with the priority of women, children and adolescents are a process of women, children and adolescents are a process that allows each individual to fulfill his choices wisely because as a human being with quality can function and have more abilities. Therefore, human empowerment and development must be translated as an effort to improve the functions and abilities of individuals to be able to live longer, healthier, more prosperous and respectable.

The empowerment of the group of women weaving in the village of Letmafo is a program of the TTU Regency government through the Perindagkop office. This program aims to empower production business groups in the village, including the weaving business group in Letmafo village, Insana Tengah District. Group empowerment is an effort made by the group through the activities of providing skills, developing knowledge, strengthening the ability or potential that supports so that independence can be created.

Based on the results of interviews and direct observations at the research location, the empowerment program for a group of women weaving in the village of Letmafo consists of:

a. Technical Training Technical training is an activity organized by an institution to train and improve capabilities and skills in a particular task area. This activity is organized by 
450 | Jurnal Ilmiah Ilmu Administrasi Publik: Jurnal Pemikiran dan Penelitian Administrasi Publik

Volume 10 Number 2, July-December 2020. Page 446-453

the North Central Timor Regency government through the related offices to improve the capabilities and skills of the weaving group in the village of Letmafo. This activity has a positive impact on the weaving group in Letmafo Village, namely the woven fabric produced by various motifs and of good quality and value for sale.

b. Institutional Development Based on the results of interviews with the weaving groups in Letmafo village, in general, it is said that institutional management has never been carried out by either the relevant agencies or the village government. activities that are usually carried out are in the form of education and technical training on weaving and bookkeeping. Meanwhile, capacity building related to organizational structure and the division of tasks within groups or organizations is not yet understood. This has an impact on the overlapping of tasks in the Letmafo village weaving group organization.

c. Capital Assistance Fund / capital assistance is the provision of money / goods / services from an institution to a specific group or individual whose allocation has been specifically determined, which aims to support and facilitate the implementation of institutional activities. In carrying out weaving activities, weaving groups in Letmafo village receive funds from the government to support and facilitate weaving activities. The capital assistance provided is not sufficient so that it does not have a significant impact on the weaving groups.

d. Equipment Assistance Equipment assistance is the provision of assistance from the government in the form of tools or facilities from the government to groups or individuals with the aim of supporting group activities or activities. Weaving groups in Letmafo Village, Insana Tengah Subdistrict, are targets of empowerment from the government. In the empowerment activity these groups received assistance in the form of tenu tools and yarn winding tools. The assistance provided by the government for weaving groups is not sufficient, so that it has not had an important impact on the weaving groups in the village.

\section{The Socio-Economic Impact of the Letmaffo Village Weaving Ikat Women's Group}

Impact means any changes that occur in the environment due to human activities (Suratmo, 2004). Impact in other words also means, the consequences before and after 'something'. Social impact is a study conducted on the social and economic conditions of the community as a result of the implementation of a development activity in an area or area (Badudu, 2006). Soerjono Soekanto (2002) argues that social interactions are dynamic social relationships, which involve individual relationships between human groups, as well as between individuals and groups of humans. So it can be concluded that the impact is the result of an action or human activity in social life, empowerment and development.

Social impacts are changes that occur in humans and communities caused by development activities. Sadharto in (Wawan, 2015,). Social impacts arise when there is an activity: a project, program, or policy applied to a community. This form of intervention affects the balance in a community system. This influence can be positive or negative. Gillmore (1981 in Rahma, 2010) says that social impacts are very difficult to understand because cases in one area will be different from other areas, relationships between people or groups in community conditions are based on a system of values and symbolic meanings. In a dynamic form, social relationships will take the form of social interactions between individuals and groups in the community. 
Hilaria Diana Wati Nese Tuames, Petrus Kase, Nursalam; Analysis of Socio-Economic ... $\mid 451$

The formation of a social relationship system in a society is always influenced by environmental conditions, including the physical environment as well as the social environment. Therefore, the dynamics of changes in environmental conditions always affect the dynamics of changes in the system of social relations prevailing in a society as well as being influenced by the condition of the population in the community concerned.

Social impact analysis is a study conducted on the social, economic and cultural conditions of the community as a result of the implementation of a development activity in an area or area. The study was carried out to examine and analyze the various impacts that occurred, both positive and negative, from each activity stage starting from the pre-construction stage to the construction stage to the operation stage Frank, in (Gilbert, 2018). The impact of a development project on socio-economic aspects, especially for developing countries, is found in the following components which are determined as socio-economic indicators, namely (1) employment, (2) development of economic structures, namely the emergence of other economic activities as a result of the project such as shops. , stalls, restaurants, transportation, and others, (3) increasing community income, (4) public health, (5) community perception, (6) population growth, and so on. (Suratmo, 2004). So that the socio-economic impact can be interpreted as a change that arises as a result of activities that affect the socio-economic environment, both in terms of employment opportunities, income and welfare. Job opportunity is an opportunity that someone hopes to get a job. Program success is the achievement of results in accordance with predetermined goals.

The success of the Letmaffo Village Weaving Ikat Women's Group Empowerment program will be analyzed based on indicators of socio-economic impact including:

\section{a. Employment}

Labor absorption is the population who are able to work at the working age consisting of people who are looking for work, have jobs but are temporarily unemployed or unemployed. Employment absorption is the amount of labor absorbed in a particular business.

Weaving group is a group business unit formed by women who have creativity in weaving. The formation of weaving groups can absorb labor / reduce the number of unemployed women in the village. This is because the weaving group is a productive group so that it has a good impact on increasing the per capita income of the community. Potential productive groups motivate additional groups. Where initially there was only one group formed, but in its development it increased significantly even though some groups were not confirmed, but in general the weaving activities carried out were formed in groups. which illustrates that the absorption of labor is indicated by the increase in the number of group members after the empowerment activity for the weaving group in Letmafo village.

\section{b. Household Economy Improvement}

Economic improvement is the process of changing the economy / income within a certain period of time to lead to a better economic condition. An increase in the household economy experiencing economic growth is indicated by a better life in the community. Based on the results of research on the weaving group in Letmafo village, it shows that there has been no improvement in the community's economy, the economic condition of group members is still stagnant and even declining. This is because the productivity of the group's woven cloth has decreased due to the use of traditional production tools, the lack of enthusiasm of the women's groups in applying creativity and the results of training after the empowerment activities of the government through related agencies. 
$45^{2}$ Jurnal Ilmiah Ilmu Administrasi Publik: Jurnal Pemikiran dan Penelitian Administrasi Publik

Volume 10 Number 2, July-December 2020. Page 446-453

\section{c. Development of Group Economic Structure}

One of the objectives of the Letmafo village weaving group is to have a marcket place and branches in the marketing of woven fabrics so that the woven fabric is increasingly known and the price for woven fabrics can increase. However, based on the results of interviews and observations at the research location, the economic structure of the group was not sufficient. So that some weaving activities still use traditional patterns or methods. so it is difficult to achieve increased production and open a special place for the sale of these woven fabrics.

\section{d. Perceptions of Group Members}

The perspective of group members regarding the empowerment of the weaving group can be seen that the level of community participation in the weaving activity is very good. This is marked by the enthusiasm of the community who have the initiative to form and finance the continuity of the activity process in the group. The activity carried out was a group effort confirmed by the village head and data on the Perindagkop office so that the group formed had legality.

\section{CONCLUSION}

The empowerment program for the weaving women's group by the North Central Timor Regency government through the Industry, Trade and Cooperative Service (PERINDAGKOP) has not had a maximum impact on the socio-economic life of the ikat group in Letmafo Village, Insana Tengah District.

The socio-economic impact consists of: 1) Labor absorption, the women's empowerment program for the weaving group in Letmafo Village has a positive impact on labor absorption, namely an increase in the number of weaving groups after there is an empowerment program from the government through related agencies. 2) Increasing the household economy, in this indicator, has not had a positive impact on improving the economy of the people who are members of the women's group weaving ikat. This is known through the per capita income of the community, which is stagnant and even decreases because the production of woven fabrics is small and difficult to market. 3) One of the goals of the Letmafo village weaving group is to have a marcket place and branches in the marketing of woven fabrics so that the woven fabric is increasingly known and the price for woven fabrics can increase. However, the research results obtained from the economic structure of the group are inadequate. So that some weaving activities still use traditional patterns or methods. so it is difficult to achieve increased production and open a special place for the sale of these woven fabrics. 4) Perceptions of members The community perception group regarding the weaving activity is very good. This is marked by the enthusiasm of the people who have the initiative to form and continue the activity process in groups. The activity carried out was a group effort confirmed by the village head and data on the Perindagkop office so that the group formed had legality.

Referring to this description, the socio-economic impact through the empowerment program by the TTU Regency government on the group of women weaving in the village of Letmafo has not had a maximum positive impact on labor absorption, improving the community economy and institutions. 
Hilaria Diana Wati Nese Tuames, Petrus Kase, Nursalam; Analysis of Socio-Economic ... $\mid 453$

\section{REFERENCES}

Badudu J.S. 2006. Kamus Besar Bahasa Indonesia Cetakan Kesebelas. Jakarta: Pustaka Sinar Harapan.

Dean Gilbert Mahino, dkk. 2018. Dampak Sosial Ekonomi Melalui Program Kelompok Usaha Bersama (KUBE) Dalam Meningkatkan Kesejahteraan Masyarakat. Jurnal EKSEKUTIF VOL.1, NO,1.

Raharjana. 2005. Pengembangan Desa Wisata Berbasis Budaya, Studi Kasus di Desa Wisata Ketingan, Tesis Yogyakarta. Gajah Mada University Press.

Sadharto, P.Hadi. 1995. Aspek Sosial Amdal, Yogyakarta: Gajah Mada University Press

Suratmo, Gunawan. 2014. Analisis Dampak Lingkungan, Yogyakarta: Gajah Mada University Press.

Sugiyono. 2002. Metode Penelitian Administrasi. Bandung : CV Alfabeta

Wawan Kurniawan, 2015. Dampak Sosial Ekonomi Pembangunan Pariwisata Umbul Sidomukti Kecamatan Bandungan Kabupaten Semarang. 